\title{
Demography and life history of Daucus carota L. populations in the Netherlands
}

\author{
Tom J. de Jong ${ }^{\mathrm{a}, *}$, Cilia Grebenstein ${ }^{\mathrm{a}, \mathrm{b}}$, Wil L.M. Tamis ${ }^{\mathrm{b}}$ \\ a Institute of Biology, Leiden University, PO Box 9505, 2300 RA Leiden, The Netherlands \\ ${ }^{\mathrm{b}}$ Institute of Environmental Sciences, Leiden University, PO Box 9518, 2300 RA Leiden, The Netherlands
}

\section{A R T I C L E I N F O}

\section{Article history:}

Received 18 January 2016

Received in revised form 9 July 2016

Accepted 22 July 2016

Edited by Hermann Heilmeier

Available online 26 July 2016

\section{Keywords:}

Carrot

Annual

Monocarpic perennial

Life history

Threshold size for flowering

Introgression

\begin{abstract}
A B S T R A C T
In nature so-called 'biennial' plants often delay their life cycle, flowering in the third or fourth year, or even later. Life-history theory predicts that high rosette survival is associated with longer life histories. We test this in wild carrot (Daucus carota) populations along disturbed roadsides in the Netherlands, covering a range from unfertile to highly fertile soils. Only $24.2 \%$ of the plants behaved as biennial or monocarpic perennial. Most plants were winter (38.9\%) or summer annual (36.8\%). There was no significant association between life history and habitat, despite differences in mortality and soil fertility between the populations. Annual rosette survival was between 19\% and 80\%, indicating a high turnover of populations. As predicted by life history theory, the fraction summer annuals (the shortest life-cycle) decreased significantly with rosette survival. In five populations the fraction plants flowering increased with plant size in a similar manner, but in the North Holland dune population plants had a higher threshold size. The annual behaviour of the carrots is quite different from their monocarpic perennial life cycle described in other studies. Carrot cultivars may cross with wild carrots and in this way generation time of the offspring can be affected. We discuss how this may affect plant fitness in the wild.
\end{abstract}

(c) 2016 Elsevier GmbH. All rights reserved.

\section{Introduction}

Selection on generation time involves a trade-off between reduced survival and more accumulation of resources for reproduction (Metcalf et al., 2003). Biennial plants are adapted to semi-disturbed conditions (Harper, 1977), where they profit from disturbances to establish or re-establish local populations. Lifehistory theory predicts that low rosette survival favours annuals with a shorter generation time than biennials (Hart, 1977; de Jong and Klinkhamer, 2005). High rosette survival favours monocarpic perennials that delay flowering past the second year. In monocarpic perennials the probability of flowering typically increases with plant size and this can be quantified as the threshold size at which $50 \%$ of the plants in a population flower (de Jong and Klinkhamer, 2005). Comparing habitats at the same latitude, Wesselingh et al. (1997) documented that high rosette survival corresponded with a higher threshold size for flowering in the monocarpic perennial Cynoglossum officinale. Several studies showed that generation time changes with latitude, with shorter life histories (annuals)

\footnotetext{
* Corresponding author.

E-mail addresses: t.j.de.jong@biology.leidenuniv.nl, tomdejong@yahoo.com (T.J. de Jong).
}

becoming more predominant towards the south (Lacey, 1988 for Daucus carota in North America; Boudry et al., 2002 for Beta maritima in Europe) and these changes are partly genetic, i.e. plants from different latitudes differ in generation time when placed in the same environment. In a common garden, accessions of the perennial Lythrum salicaria from the north of Sweden started reproduction later than southern accessions (Olsson and Agren, 2002). Contrary to this, in the US Arabidopsis lyrata accessions from northern locations showed a higher fraction flowering than plants from southern accessions when grown under the same conditions (Paccard et al., 2014). Kim and Donohue (2011) showed that the perennial Erysimum capitatum delayed reproduction later at higher altitude, where plant survival was higher. The predominance of annuals in the south may well represent greater disturbance and higher rosette mortality but these factors were rarely measured directly and other factors may also contribute to clines in generation time. Clines may also change as a result of the climate becoming warmer. Van Dijk and Hautekèete (2014) showed that plants of Beta maritima originating from seeds collected in 2009 flowered more often in their first year than the seeds collected in 1989 at the same location.

We studied the demography of wild Daucus carota subsp. carota $\mathrm{L}$ populations along roadsides in the Netherlands. In the Netherlands the wild carrot is widespread in these disturbed 
habitats (FLORON, 2011), yet its life history has rarely been studied. Wild carrot is fully outcrossing and crosses easily with the carrot crop, D. carota subsp. sativa (Wijnheimer et al., 1989; Hauser and Bjorn, 2001; Rong et al., 2014). Wild carrot is a monocarpic perennial plant that is native to Europe (Heywood, 1983). It has been observed to flower in the first year (Gross, 1981; Schouten et al., 2002) but often delays flowering until a more substantial size has been reached. Both genetic factors and the suitability of the environment determine the age at which plants flower in the field (Hauser and Shim, 2007).

We address the following predictions from life history theory. (1) Is the shortening of the life cycle associated with high rosette mortality? (2) Does the size threshold for flowering differ between populations and does it decrease with high rosette mortality? These questions are examined for six Dutch $D$. carota populations that vary greatly in soil fertility. We also expect that fraction of annuals increases with nutrient availability, simply because more nutrients allow more growth and will allow more plants to reach the size threshold for reproduction sooner.

\section{Material and method}

\subsection{Species description}

Daucus carota is a short-lived monocarpic herb that flowers from June until autumn. The spiny one-seeded fruits are likely to be animal-dispersed and may lie dormant in the soil for more than 1 or 2 years. Populations of wild carrots are very common along roadsides, cultivated fields and in early succession wastelands across most of Europe, but the species also occurs in late-successional grasslands. Wild carrots are considered weeds in North America and Japan, where they have been introduced (Hauser et al., 2004; Umehara et al., 2005).

\subsection{Habitat characterization}

Two populations were located at the landward side of coastal sand dune areas, one in Bergen $\left(52^{\circ} 35^{\prime} 02.39^{\prime \prime} \mathrm{N}, 4^{\circ} 39^{\prime} 19.12^{\prime \prime} \mathrm{E}\right.$; North Holland ( $\mathrm{NH})$ dunes) and one in Meijendel ( $52^{\circ} 07^{\prime} 45.90^{\prime \prime} \mathrm{N}$, $4^{\circ} 21^{\prime} 20.63^{\prime \prime} \mathrm{E}$; South Holland (SH) dunes); two populations were located in polder areas, one in Roosendaal $\left(51^{\circ} 33^{\prime} 19.16^{\prime \prime} \mathrm{N}\right.$, $\left.4^{\circ} 24^{\prime} 43.75^{\prime \prime} \mathrm{E}\right)$ and one in the Schermerpolder $\left(52^{\circ} 35^{\prime} 51.53^{\prime \prime} \mathrm{N}\right.$, $43^{\prime} 34.25^{\prime \prime} \mathrm{E}$; Schermer); one was an urban population located in Leiden $\left(52^{\circ} 08^{\prime} 58.47^{\prime \prime} \mathrm{N}, 4^{\circ} 27^{\prime} 31.44^{\prime \prime} \mathrm{E}\right)$ and one was a riverine population located near Leerdam ( $\left.51^{\circ} 50^{\prime} 48.86^{\prime \prime} \mathrm{N}, 5^{\circ} 05^{\prime} 38.03^{\prime \prime} \mathrm{E}\right)$.

All populations were mown twice a year in early to mid-June and during September. This is a typical management regime for Dutch roadsides. Mowing can affect the early bolters and flowering plants, which then typically regrow to resume flowering and seed production, until the second mowing. An exception was the Leiden population that was mown later, in late July and late October. In order to characterize the environmental conditions of the six populations, soils samples were collected from the $0-25 \mathrm{~cm}$ layer and analysed for total Nitrogen by BLGG Agroxpertus, Wageningen, The Netherlands.

\subsection{Field survey}

Individual plants were marked in an area of $12 \mathrm{~m}^{2}$, their position was recorded and plants were then intensively followed from 2009 to 2010. We visited the plots in spring (April-May 2010) for counting emerging seedlings and rosettes and in the autumn (August-September 2010) for counting seedlings, established rosettes and flowering plants (Fig. 1). In June 2010 the number of leaves was counted and length of the longest leaf was measured. Length of the longest leaf $(x)$ best predicted Dry Weight
(DW) of the whole plant in June ( $n=10$, South Holland dunes). The regression equation $\ln (D W)=2.63 \ln (x)-12.47$ explained $94.2 \%$ of the variation in $\ln (D W)$. Root Crown Diameter (91.3\%) and Number of Leaves (83.0\%) did less well in this respect. During autumn 2009 we distinguished seedlings from older rosettes, by size and appearance. Then we counted seedlings and rosettes again during spring 2010 and counted the plants again in autumn 2010 to record which ones had died, survived as rosette or flowered. With this scheme we could distinguish different flowering strategies (Fig. 1). Plants that were in the rosette stage during fall $2009\left(N_{1}\right)$ and that flowered during fall $2010\left(N_{3}\right)$ had a biennial or, if they were already older than one year at the first census, monocarpic perennial life history. Plants that germinated during fall $2009\left(N_{4}\right)$ and flowered in the next year $\left(N_{6}\right)$ were winter annuals. Plants that germinated in spring $2010\left(N_{7}\right)$ and flowered a few months later $\left(N_{9}\right)$ had an even shorter summer-annual life history. During 2011 the monitoring of the plots was less intensive. No seedlings were marked but we did record the survival of older rosettes from autumn 2010 until the same moment next year. Consistent with the literature (Verkaar and Schenkeveld, 1984), we observed in our plots that wild carrot seeds germinated throughout the year. Therefore the distinction we made between winter and summer annuals is artificial. It depends on whether the seeds had germinated before or after our autumn census. Summer annuals will include plants that germinated in, for instance, March and that were exposed to some winter cold as seedlings. The cold required for flowering of carrots is quite variable and ranges between cultivars from 5 days to 3 months (Nemeth, 2003). Over the two years that our study lasted the populations in $\mathrm{NH}$ dunes, Leerdam, Roosendaal and Schermer showed an overall increase, whereas the SH Dunes population remained stable and the Leiden population decreased.

\subsection{Plant size and probability of flowering}

We performed logistic regression using the $\mathrm{R}$ ( $\mathrm{R}$ Development Core Team, 2011) procedure GLM, family = binomial link= logit) to connect vegetative $(0)$ or flowering $(1)$ to the biomass proxy length of the longest leaf $(x)$. In the logistic regression $y=1 /(1+\exp (-\mu-$ $\alpha x)$ ) parameter $\alpha$ quantifies the effect of leaf length $x$ on flowering probability. Significant differences in model parameters between the different populations were examined with a $t$-test (Holmes et al., 2011).

\section{Results}

\subsection{Survival and flowering}

Averaged over 2010 and 2011 rosette survival was highest in the two dune populations and lowest in the inland populations (Table 1). Rosette mortality in 2010 was highly correlated to mortality in 2011 (Spearman rank correlation, $r_{s}=0.87$, twosided $P=0.05$ ), showing that some populations consistently have high annual rosette mortality. There was no significant association between life history and population $\left(\chi^{2}=5.27, \mathrm{df}=10, P=0.87\right.$, Table 1). On average $24.2 \%$ of all flowering plants was monocarpic perennial or biennial, $38.9 \%$ was winter annual and $36.8 \%$ was summer annual (Table 1). Dune populations had only $27.3-33.3 \%$ monocarpic perennials and a similar fraction was also present in the Roosendaal $(24.0 \%)$ and Leiden $(28.6 \%)$ populations. The soil on the different sites differed markedly in its Nitrogen content (Table 1 ). The fraction of summer annuals, the shortest life history, was strongly negatively correlated with rosette survival $\left(r_{s}=-0.88\right.$, two-sided $P=0.03$, Fig. $2 \mathrm{a}$ ), as predicted by life history theory. The fraction summer annual plants increased with soil fertility $\left(r_{s}=0.6\right.$, two-sided $P=0.24$, Fig. $2 \mathrm{~b}$ ) as expected because more nutrients 


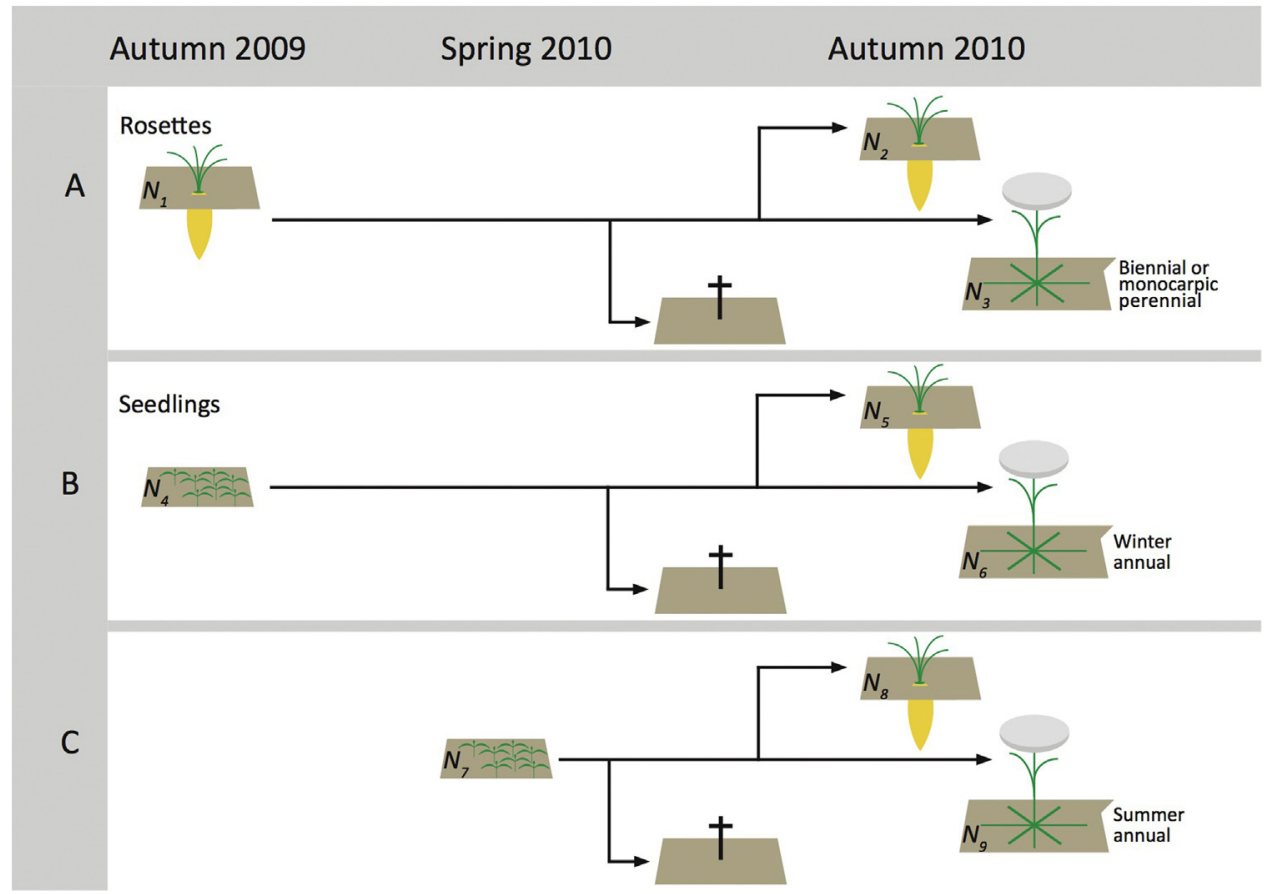

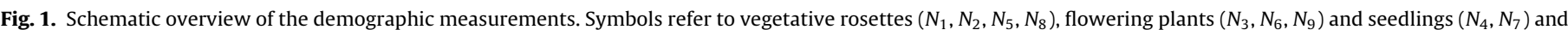

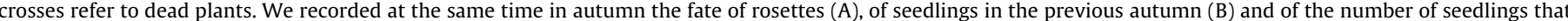
had germinated in spring (C).

Table 1

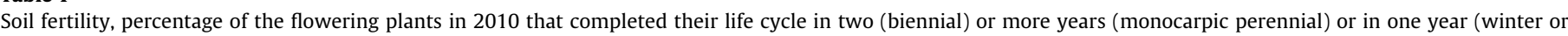
summer annual) according to the scheme of Fig. 1 and annual rosette survival in six populations of Daucus carota in the Netherlands.

\begin{tabular}{|c|c|c|c|c|c|c|c|}
\hline Population & $\begin{array}{l}\text { Nitrogen mg } \\
\mathrm{N} / \mathrm{kg}\end{array}$ & $\begin{array}{l}\text { No. flowering } \\
\text { plants }\end{array}$ & $\begin{array}{l}\% \text { Biennial/monocarpic } \\
\text { perennial }\end{array}$ & $\%$ Winter annual ${ }^{\mathrm{a}}$ & $\begin{array}{l}\text { \% Summer } \\
\text { annual }\end{array}$ & $\begin{array}{l}\text { \% Rosette survival } \\
(n) 2010\end{array}$ & $\begin{array}{l}\text { \% Rosette survival } \\
(n) 2011\end{array}$ \\
\hline SH dunes & 199 & 15 & 33.3 & 40.0 & 26.7 & $80.0(10)$ & $61.9(21)$ \\
\hline NH dunes & 860 & 22 & 27.3 & 40.9 & 31.8 & $53.3(15)$ & $33.3(6)$ \\
\hline Leiden & 1260 & 14 & 28.6 & 28.6 & 42.8 & $19.0(21)$ & $25.0(4)$ \\
\hline Roosendaal & 2320 & 25 & 24.0 & 36.0 & 40.0 & $40.0(20)$ & $35.0(20)$ \\
\hline Leerdam $^{\mathrm{b}}$ & 4500 & 10 & 0 & 50.0 & 50.0 & $27.7(18)$ & - \\
\hline Schermer & 5590 & 9 & 22.2 & 44.5 & 33.3 & $36.4(11)$ & $25.0(12)$ \\
\hline
\end{tabular}

a The most common life cycle is indicated bold.

b Markers disappeared from this site in 2011.
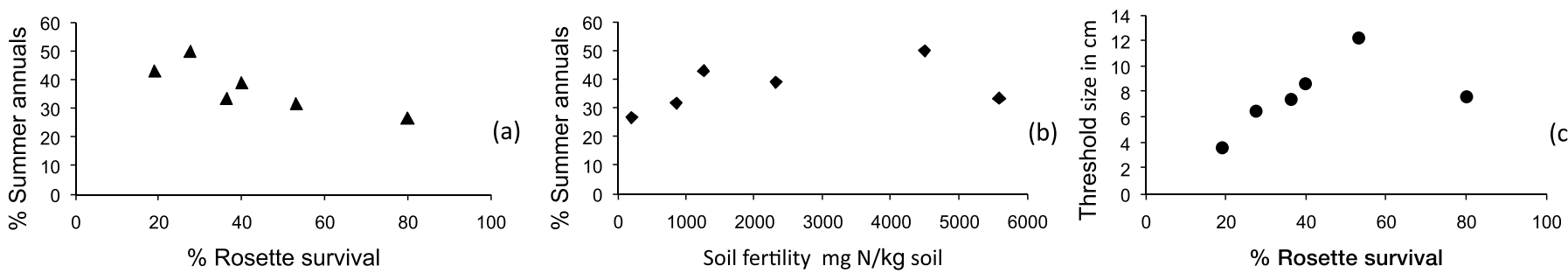

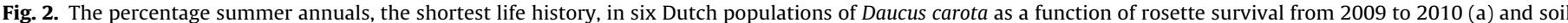
fertility (b). Threshold size, the size at which $50 \%$ of the plants flowers, as a function of rosette survival from 2009 to 2010 (c).

allow plants to grow faster and complete their life cycle more rapidly. This trend was, however, not significant over the six populations.

\subsection{Size threshold for induction of flowering}

For all populations the probability of flowering increased with plant size ( $\alpha$ was positive). This increase was significant ( 0 was outside the $95 \%$-Confidence Limits of $\alpha$, Appendix A) for all populations except for Leiden population. The $\alpha$ value of 0.140 for the
$\mathrm{NH}$ dune population is significantly lower than the $\alpha$ values for the five other populations ( $t$-test, all $t$-values $>2.56$, all $P<0.05$ ). There were no significant differences in $\alpha(P>0.05)$ between the other groups. The threshold for flowering was $12.2 \mathrm{~cm}$ for the $\mathrm{NH}$ dune population, while for the other populations it varied between $3.6 \mathrm{~cm}$ (Leiden) and $8.6 \mathrm{~cm}$ (Roosendaal). Fig. 3 also illustrates that plants in the $\mathrm{NH}$ dune population flowered at larger sizes, while flowering behaviour in the other five populations was highly similar. 


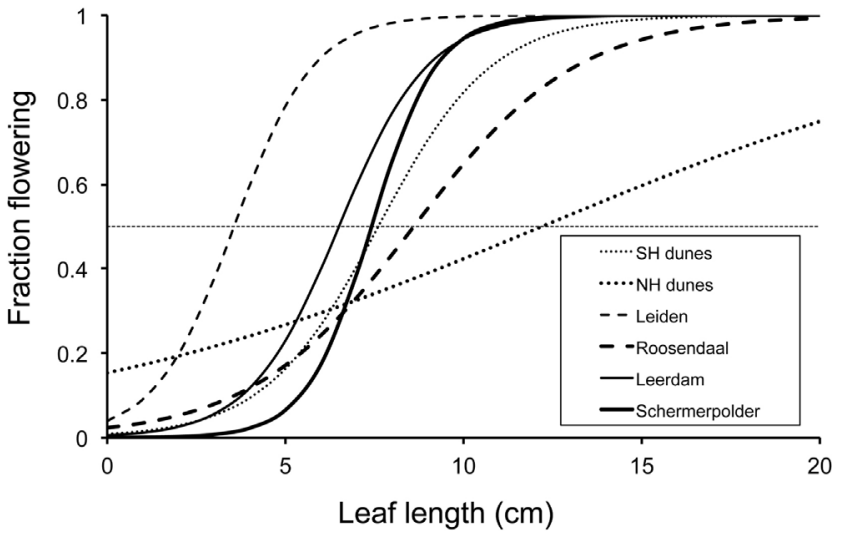

Fig. 3. The fraction flowering increases with length of the longest leaf in Daucus carota. The logistic model is $y=1 /(1+\exp (-\mu-\alpha \mathrm{x}))$, in which the parameter $\alpha$ quantifies effects of leaf size on flowering probability. The ranking from top to bottom in the boxed legend is according to soil fertility with SH dunes having the lowest (thin dotted line) and Schermer having the highest (thick solid line) soil fertility. See Appendix A for parameter values.

A high threshold size (more delay of flowering) is expected in populations with high rosette survival. The Spearman rank correlation was positive $\left(r_{s}=0.82\right)$, but not significant $(P=0.06$, Fig. $2 \mathrm{c})$.

\section{Discussion}

\subsection{Life history}

In the Dutch populations we studied most flowering plants had an annual life history. Our populations were all in disturbed habitats with low rosette survival (Table 1 ). Our results differ markedly from previous studies on carrot demography, probably because the habitats we studied were more disturbed and rosette survival was low.

In old fields in the US (Michigan, $42^{\circ} \mathrm{N}, 85^{\circ} \mathrm{W}$ ) flowering increased with plant size for wild carrot, with most plants behaving as monocarpic perennials (Holt, 1972; Gross, 1981). Under these unproductive conditions rosettes delayed flowering up to 4-5 years and during this time rosette survival was high ( $>90 \%$ ). Gross and Werner (1982) emphasized for old fields in North America that, due to its large seeds, Daucus carota could even establish in latesuccessional vegetation. Verkaar and Schenkeveld (1984) studied the fate of a cohort of $D$. carota in chalk grassland in the south of the Netherlands. In this unproductive habitat all carrot plants adopted a monocarpic perennial life-history; none of the plants flowered in year 1 or year $2,12 \%$ of the surviving plants flowered in year 3 , $11 \%$ in year 4 and in year 5 many plants that had not yet flowered were still alive. Rosette survival in these populations was higher than $90 \%$ per year.

\subsection{Adaptation}

Comparison with other studies suggests that rosette survival is a key factor for explaining the shift in life history of wild carrots. Lacey (1988) found that, in the same environment, the generation time of wild carrot accessions from the south of the US was shorter than that for northern accessions. Daucus carota arrived in the US in the 17th century so that the cline in North America arose in about 300 years (Lacey, 1988). It can be hypothesized that the difference in rosette survival, presumably lower in the south of the US, is the driving force behind the cline. In our study the fraction of summer annuals, the shortest life history, decreased with survival (Fig. 2a). This is in line with theory. It should be emphasized however that the differences between populations in life history and threshold size are very small. This is surprising considering the rather different habitats we considered over a broad range of soil fertilities. The maximum distance between the two most distant populations (NH dunes-Roosendaal) is about $100 \mathrm{~km}$. Perhaps gene flow between populations restricts local adaptation. The minimum recommended isolation distance for producing seeds of cultivated carrots is more than $1000 \mathrm{~m}$ (carrotmuseum.co.uk), showing that flies and bees can transport pollen over large distances.

One could further pursue genetic differentiation between populations by growing plants in a common environment. Wesselingh et al. $(1993,1997)$ followed this approach for the monocarpic perennial Cynoglossum officinale. They found marked differences in threshold size between populations at the same latitude in dunes in the UK and in the South Holland dunes in the Netherlands. Threshold size was higher in the UK populations, corresponding with higher rosette survival. Williams (2009) found that $C$. officinale flowered at a larger size in areas where it was introduced and in these introduced areas rosette survival was higher. For wild carrots the life history in the six habitats we studied was so similar that one would not expect such marked genetic differences for threshold size for flowering, as were documented for C. officinale. Genetic differences between our six populations are probably minimal. For further comparisons in a standard environment, it would then be advisable to also sample in Europe over large geographic distances, as Lacey (1988) did for the US, and/or to compare populations introduced into the US with European populations.

\subsection{Introgression}

When crops are able to cross with their wild relatives, there is a potential for gene flow and for introgression, the incorporation of crop alleles into the wild population. Crop-to-wild gene flow occurred since humans introduced agriculture but it recently received renewed interest in the context of genetically modified crops (Ellstrand et al., 2013). Several papers showed that such gene flow exists and occasionally leads to introgression (Magnussen and Hauser, 2007 for carrot; Kwit et al., 2011; Ellstrand et al., 2013). Schouten et al. (2002) already considered the possibility that resistance alleles against the fungus Alternaria dauci could move from cultivated carrot to wild populations. To predict whether introgression is likely to occur, one needs information on the seed production and survival of hybrids. Perhaps some crop genes confer a selective advantage in the wild, but they are inherited together with domestication genes and this may stop their spread. This was the topic of some recent theoretical (Ghosh et al., 2012; de Jong and Rong, 2013) and experimental papers (Hartman et al., 2014). Cultivated carrots have been bred for vernalization requirement (Allessandro and Galmarini, 2007), i.e. a period of cold temperatures is necessary for flowering to occur. In this way the swollen hypocotyls can be harvested and stored for consumption. Consequently carrot crops have a strong vernalization requirement for flowering and a biennial life history. If their wild relative has a similar life history there is no disadvantage to these domestication genes. However, when life histories differ there is a barrier for introgression. Vernalization requirement is a recessive character in carrot, so that all F1 plants can flower in their first year. In the Netherlands gene flow from crop to wild could occur through bolters in cultivated carrot. Such bolters likely result from contamination of seeds from seed growing areas in the south. Gene flow could also occur through cultivated carrots that are left in the field, receive winter cold and then flower in their second year. In the latter case introgression is less likely since the life histories of crop and wild plant differ and hybrids may have reduced fitness. 


\section{Acknowledgements}

Many thanks to Erik Gertenaar and Sonja Esch for helping with fieldwork. Thanks also go to Geert de Snoo for discussions. This work was supported by the research program 'Ecology Regarding Genetically Modified Organisms' (ERGO) No. 838.06.031 of the Dutch Ministries for the Environment, Economic Affairs, Agriculture and Science and Education, implemented by the Earth and Life Sciences Council (ALW) of the Netherlands Organisation for Scientific Research (NWO).

\section{Appendix A. Parameters of the logistic regression for fraction flowering as a function of leaf size for the six populations.}

Sweet, J. (Eds.), Introgression from Genetically Modified Plants into Wild Relatives. CABI Publishing, Wallingford UK, pp. 41-51.

Heywood, H.V., 1983. Relationships and evolution in the Daucus carota complex. Israel J. Bot. 32, 51-65.

Holmes, D., Moody, P., Dine, D., 2011. Research Methods for the Biosciences. Oxford University Press, Oxford UK.

Holt, B.R., 1972. Effect of arrival time on recruitment, mortality, and reproduction in successional plant populations. Ecology 53, 668-673.

Kim, E., Donohue, K., 2011. Demographic, developmental and life-history variation across altitude in Erysimum capitatum. J. Ecol. 99, 1237-1249.

Kwit, C., Moon, H.S., Warwick, S.I., Stewart, C.N., 2011. Transgene introgression in crop relatives: molecular evidence and mitigation strategies. Trends Biotechnol. 29, 284-293.

Lacey, E.P., 1988. Latitudinal variation in reproductive timing of a short-lived monocarp, Daucus carota (Apiaceae). Ecology 69, 220-232.

Magnussen, L.S., Hauser, T.P., 2007. Hybrids between cultivated and wild carrots in natural populations in Denmark. Heredity 99, 185-192.

\begin{tabular}{|c|c|c|c|c|c|c|}
\hline Population & Leaf size range $(\mathrm{cm})$ & $\mu \pm 1$ S.E. $^{\mathrm{a}}$ & $\alpha \pm 1$ SE. $^{\mathrm{a}}$ & $\mathrm{TS}^{\mathrm{b}}$ & $\% \mathrm{~F}^{\mathrm{C}}$ & $n^{\mathrm{d}}$ \\
\hline SH Dunes & $2-18$ & $-4.771 \pm 1.106$ & $0.627 \pm 0.183$ & 7.6 & 37.14 & 62 \\
\hline NH Dunes & $2-93$ & $-1.708 \pm 0.504$ & $0.140 \pm 0.051$ & 12.2 & 41.94 & 63 \\
\hline Leiden & $1-26$ & $-3.202 \pm 2.265$ & $0.899 \pm 0.530$ & 3.6 & 72.22 & 19 \\
\hline Roosendaal & $2-22$ & $-3.760 \pm 0.709$ & $0.437 \pm 0.111$ & 8.6 & 41.46 & 100 \\
\hline Leerdam & $2-21$ & $-5.235 \pm 1.308$ & $0.805 \pm 0.240$ & 6.5 & 36.84 & 65 \\
\hline Schermer & $2-19$ & $-8.163 \pm 2.234$ & $1.101 \pm 0.353$ & 7.4 & 36.84 & 64 \\
\hline
\end{tabular}

aparameters from the logistic regression $y=1 /(1+\exp (-\mu-\alpha x))$, in which $\alpha$ quantifies effects of leaf length $x$ on flowering probability.

bTS: threshold size, i.e. leaf length $(\mathrm{cm})$ at which $50 \%$ of the plants flower.

c\%F: percentage of flowering plants.

${ }^{\mathrm{d}} n=$ sample size.

\section{References}

Allessandro, M.S., Galmarini, C.R., 2007. Inheritance of the vernalization requirement in carrot. J. Am. Soc. Hortic. Sci. 132, 525-529.

Boudry, P., Mccombie, H., van Dijk, H., 2002. Vernalization requirement of wild beet Beta vulgaris ssp: maritima: among population variation and its adaptive significance. J. Ecol. 90, 693-703.

de Jong, T.J., Klinkhamer, P.G.L., 2005. Evolutionary Ecology of Plant Reproductive Strategies. Cambridge University Press, Cambridge UK.

de Jong, T.J., Rong, J., 2013. Crop to wild gene flow: does more sophisticated research provide better risk assessment? Environ. Sci. Policy 27, 135-140.

Ellstrand, N.C., Meirmans, P., Rong, J., Bartsch, D., Ghosh, A., de Jong, T.J., Haccou, P., Lu, B., Snow, A.A., Stewart Jr., N.N., Strasburg, J.L., van Tienderen, P.H., Vrieling K., Hooftman, D., 2013. Introgression of crop alleles into wild or weedy populations. Ann. Rev. Ecol. Evol. Syst. 44, 325-345.

FLORON, 2011. Nieuwe atlas van de Nederlandse Flora. FLORON, Leiden.

Ghosh, A., Meirmans, P.G., Haccou, P., 2012. Quantifying introgression rates with realistic population growth. Proc. R. Soc. B Biol. Sci. 279, 4747-4754.

Gross, K.L., Werner, P.A., 1982. Colonizing abilities of biennial plant species in relation to ground cover: implications for their distribution in a successional sere. Ecology 63, 921-931.

Gross, K.L., 1981. Predictions of fate from rosette size in four biennial species: Verbascum thapsus, Oenothera biennis, Daucus carota and Tragopogon dubius. Oecologia 48, 209-213.

Harper, J.L., 1977. Population Biology of Plants. Academic Press, London UK.

Hart, R., 1977. Why are biennials so few? Am. Nat. 111, 792-799.

Hartman, Y., Hooftman, D.A.P., Uwimana, B., Schranz, M.E., van de Wiel, C.C.M., Smulders, M.J.M., Visser, R.G.F., Michelmore, R.W., van Tienderen, P.H., 2014. Abiotic stress QTL in lettuce crop-wild hybrids: comparing greenhouse and field experiments. Ecol. Evol. 4, 2395-2409.

Hauser, T.P., Bjorn, G.K., 2001. Hybrids between wild and cultivated carrots in Danish carrot fields. Genet. Resour. Crop Evol. 48, 499-506.

Hauser, T.P., Shim, S.I., 2007. Survival and flowering of hybrids between cultivated and wild carrots (Daucus carota) in Danish grasslands. Environ. Biosaf. Res. 2007, 237-247.

Hauser, T.P., Bjorn, G.K., Magnussen, L., Shim, S.I., 2004. Hybrids between cultivated and wild carrots: a life history. In: den Nijs, H.C.M., Bartsch, D.

Metcalf, J.C., Rose, K.E., Rees, M., 2003. Evolutionary demography of monocarpic perennials. Trends Ecol. Evol. 18, 471-480.

Nemeth, E., 2003. Caraway: the Genus Carum. CRC Press, Boca Raton US.

Olsson, K., Agren, J., 2002. Latitudinal population differentiation in phenology, life history and flower morphology in the perennial herb Lythrum salicaria. J. Evol. Biol. 15, 983-996.

Paccard, A., Fruleux, A., Willi, Y., 2014. Latitudinal trait variation and response to drought in Arabidopsis lyrata. Oecologia 175, 577-587.

R Development Core Team, 2011. R: A Language and Environment for Statistical Computing. R Foundation for Statistical Computing, Vienna, Austria.

Rong, J., Lammers, Y., Strasburg, J.L., Schidlo, N.S., Ariyurek, Y., de Jong, T.J., Klinkhamer, P.G.L., Smulders, M.J.M., Vrieling, K., 2014. New insights into domestication of carrot from root transcriptome analysis. BMC Genomics 15, 895.

Schouten, H.J., van Tongeren, C.A.M., van den Bulk, R.W., 2002. Fitness effects of Alternaria dauci on wild carrot in the Netherlands. Environ. Biosaf. Res. 1 , 39-47.

Umehara, M., Eguchi, I., Kaneko, D., Ono, M., Kamada, H., 2005. Evaluation of gene flow and its environmental effects in the field. Plant Biotechnol. 22, 497-504.

Van Dijk, H., Hautekèete, N.-C., 2014. Evidence of genetic change in the flowering phenology of sea beets along a latitudinal cline within two decades. J. Evol. Biol. 27, 1572-1581.

Verkaar, H.J., Schenkeveld, A.J., 1984. On the ecology of short-lived forbs in chalk grasslands: life-history characteristics. New Phytol. 98, 659-672.

Wesselingh, R.A., de Jong, T.J., Klinkhamer, P.G.L., van Dijk, M.J., Schlatmann, E.G.M., 1993. Geographical variation in threshold size for flowering in Cynoglossum officinale. Acta Bot. Neerl. 42, 81-91.

Wesselingh, R.A., Klinkhamer, P.G.L., de Jong, T.J., Boorman, L.A., 1997. Threshold size for flowering in different habitats: effects of size-dependent growth and survival. Ecology 78, 2118-2132.

Wijnheimer, E.H.M., Brandenburg, W.A., Terborg, S.J., 1989. Interactions between wild and cultivated carrots (Daucus carota L) in the Netherlands. Euphytica 40, $147-154$.

Williams, J.L., 2009. Flowering strategies differ between the native and introduced ranges of a monocarpic perennial. Am. Nat. 174, 660-672. 